\title{
Women empowerment in a traditional masculine industry: Tourism in context
}

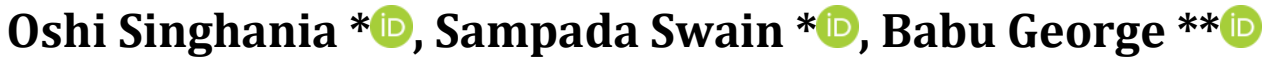

* School of Management, Pondicherry University,

Kalapet, Pondicherry 605014, India

oshi.singhania@gmail.com; sampadswain@gmail.com

** School of Business, Christian Brothers University,

650 East Parkway South, Memphis, Tennessee 38104, USA

bgeorge@cbu.edu

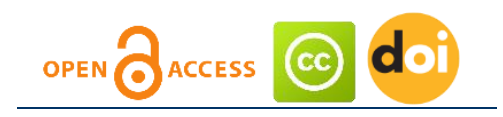

Article history:

Received: August 29, 2021

1st Revision: October 15,

2021

Accepted: November 22,

2021

\section{JEL classification:}

J16

L83

K38

DOI:

10.14254/jems.2021.6-2.5

\begin{abstract}
Tourism is considered as an essential source of generating employment, reducing poverty, and empowering women. Most of the tourism initiatives targeting poverty reduction primarily focus on providing income opportunities for women that only enhance their economic empowerment. Nevertheless, this does not usually lead to make overall development. This is attributed to the normative gender roles, cultural complexities, and power inequities that exist in societies. Additionally, most of the earlier research studies on tourism, poverty reduction, and women empowerment are also based on economic factors. Contrarily, limited studies are focused on non-economic factors. These non-economic factors are social, political, and psychological components that are essentially important for women's overall empowerment. Thus, these factors need to be studied comprehensively as they may hinder women's participation in tourism activities. Having taken this background as the underlying problem of study, this paper is an attempt to highlight the social and political barriers impeding women empowerment and investigate about tourism development in the socio-political contexts affecting women, especially in rural areas, using case studies pertaining to different tourism destinations.
\end{abstract}

Keywords: women empowerment, socio-political change, tourism development, case studies. 


\section{Introduction}

The tourism industry has emerged as one of the fastest expanding industries globally, creating employment opportunities in formal and informal sectors (Ferguson, 2011; Wilkinson \& Pratiwi, 1995) for both men and women. However, it provided ample jobs prospects for skilled, semi-skilled, and unskilled women to enter into the industry in $21^{\text {st }}$ century as compared to the $20^{\text {th }}$ century. Tourism has brought various job options for women to enter into the public domain thereby becoming independent and self-reliant. It is evidenced from the facts that women in rural areas of developing countries are shifting from agriculture to tourism due to less physical labor (Spenceley \& Meyer, 2012). Moreover, women find dignity, appreciation \& recognition in tourism jobs as there can be superior service delivery with the participation of women. For a long time, women have been primarily considered responsible for reproduction (Sahay, 1998) and are expected to stay indoors and perform their household duties without stepping out from the four walls of house to work independently.

Nevertheless, with a change in time, women are engaged in economic activities more actively than ever before. Traditionally, they are mostly involved in agriculture and informal sectors and they are concentrated in less skilled and low-wage jobs (Narayan, 2002). Women are deprived of economic benefits due to lack of technical skills (Sahay, 1998), a low level of education (Kabeer, 2005; Hosni \& Lundberg, 2005), and socio-cultural norms (Kinnaird \& Hall, 1996; Panta \& Thapa, 2018). However, tourism has given them a chance to participate and demonstrate their creativity and leadership and be visible in the mainstream economy (Kinnaird \& Hall, 1996).

Many studies have uncovered the facts that tourism has the capability to contribute in the achievement of Sustainable Development Goals and the $5^{\text {th }}$ goal is based on "Gender Equality and Women Empowerment". Gender Equality is defined as having equal opportunities, resources, and human rights for both men and women (FAO, 2010). According to Kabeer (2005), empowerment is defined as "the ability to make choices". This definition is relatable as women are always declined to make any choices and are marginalized in almost every society. Thus it is vital to achieving women's empowerment as it provides control over their lives and leads to their development.

In the majority of societies globally, men hold the dominant positions and dominate in decisions, whereas women suffer from economic dependence, male domination, the inadequacy of resources, and the burden of domestic responsibilities. In order to counter the chauvinism, the paradigm of empowerment has been added before women. The concept of empowerment is about redistribution of power or enhancement of capacity to take their own decisions. Empowerment enables women to challenge cultural norms and demand change in the prevailing practices (Kabeer, 2005). Empowerment can bring change in power structures and gender relations prevalent in societies.

Many pro-poor tourism initiatives and government policies are focussed on providing incomegenerating opportunities for women, which significantly enhanced their economic empowerment. It helps in poverty reduction and initiates a change in gender relations but to a limited extent (Ferguson, 2011). As every society is different culturally and historically, so women's issues and opportunities also vary accordingly (Wallace \& March, 1991). Therefore, limiting the ideas to economic aspects, not considering social relationships when introducing tourism initiatives and policies, can be valid for the short term. For the long-term, success of tourism development taking social and political factors into consideration is to be addressed critically Such an approach could lead to social transformation focusing on broader social change rather than just filling employment needs (Hamzic \& Ekbladh, 2017).

According to the United Nations (2015), mostly in developing regions, working women do not have access to their own income. They are not even allowed to take economic decisions in their households. It represents the power structures that exist in societies. Even after being financially independent, women are not able to attain social status and leadership roles. Therefore, it is crucial to look beyond women's economic empowerment and understand the complexities of the gendered nature of tourism employment and power relationships involved (Tucker \& Boonabaana, 2012), to identify how changes take place over time through tourism development. Further empowerment is a complex phenomenon to implement with women to be socially and economically independent. To achieve a comprehensive understanding of the benefits obtained from the tourism venture, empowerment should be measured from multiple aspects, i.e., economic, social, political, and psychological (Moswete \& Lacey, 2015). The studies related to women empowerment, socio-political change, and tourism development connecting all three aspects are limited and scattered. The paper tries to highlight the ground-breaking academic works to understand the importance of the relationship among three aspects. 
The primary objective is to highlight the socio-political barriers in the tourism industry related to women empowerment and investigate how changes in related context take place through tourism development impacting women empowerment.

\section{Methodology}

This study is conceptual in nature and based on existing secondary sources. The data and information are accumulated and organized mainly from books, academic works, journals, publications, and reports. A case study approach is being used concerning the debated issue linked with the socio-political changes in relation to women empowerment through tourism development. Accordingly, the secondary sources so collected and incorporated in this study have been analyzed and viewed to achieve the objective of this study.

\section{Results}

\section{Women and empowerment}

Poverty and disempowerment are usually interdependent. If an individual is unable to fulfil his/her basic needs and had to depend on others, it rules out the ability to exercise their own choices, and there can be no empowerment (Kabeer, 2005). Around the world, many people are below the poverty line as they do not have opportunities or resources to take control of their lives. Inequalities present in society give some people a chance to achieve greater affluence, and some are side-lined. As economic inequality is commonly observed majorly in terms of wages, inequality in social development, such as well-being, literacy, and human rights, have always been neglected. People have been discriminated based on gender, caste, religion, language, ethnicity, and even geographical location. One such discriminated group of people worldwide is women. Discrimination based on gender can be seen everywhere, and it is deep-rooted. It is one of the most significant impediments to human advancement (UNDP, 2019). For very long-time women have been confined to the household, dependent on men for their financial or social needs. Almost half of the world population consists of women, and the majority of them live under poverty with no income, power, or voice (Pritchard, 2014). They are mostly involved in childcare and household work. They are also victims of domestic violence (Tran \& Walter, 2014) and often face gender discrimination due to cultural norms and practices in society (Tucker \& Boonabaana, 2012). They are afraid of raising their voices against these issues and are therefore likely to accept them (Kabeer, 2005). As always been marginalized, women cannot negotiate better terms for themselves with their family, society, or the government, which constrains their capabilities, making them vulnerable and poverty-stricken (Pritchard, 2014). Dependent on others for survival, women often lose their pride, self-esteem, and cultural identity. Even working women who are the sole breadwinners of their family do not get enough support and access to resources that they often have to continue to work under adverse conditions (Wallace \& March, 1991).

According to the United Nations (2015) report, women's poverty rates in both developed and developing countries are higher than men. The concept of poverty is multidimensional and does not merely include economic inefficiency but also a lack of access to opportunities and an inability to achieve equal status in society (Mohanty \& Chandran, 2018). Gender discrimination is one of the perilous factors that lead women to poverty and disempowerment (Hosni \& Lundberg, 2005). It is the right of every individual to be treated equally. Therefore, it is essential to empower women to mitigate gender gaps and achieve international sustainable development goals and human rights. Empowered women help build strong nations and stable societies (UNIFEM, 2010). Feminists also focussed on establishing equal rights for women, achieving gender equality, and improving women's working conditions (Pritchard, 2014). Women Empowerment is a much-debated issue in a global scenario. Empowerment can be broadly defined as enhancing the capabilities and skills of individuals or groups (especially women), who are socially disadvantaged to have control over their lives, able to solve their problems and improve their well-being (Scheyvens, 2009). It is the process of challenging existing power structures and creating a balance between both the genders, where both men and women enjoy equal status. Such an approach to empowerment can alleviate poverty enabling women to know their capabilities and power in all spheres of life (Kabeer, 2005). It focusses on 'strategic gender needs' rather than 'practical gender needs,' which involves women's land rights, control over their bodies, and encouraging men to share domestic tasks (Scheyvens, 2009). 


\section{Tourism and women empowerment}

Tourism has proliferated rapidly in the past couple of decades around the world. Due to globalization, people can now travel to such destinations, which were less known and difficult to reach. Improved infrastructure and technological advancements have increased mobility. More and more people are taking trips to different parts of the world due to their curiosity to know the world and also due to more disposable income. People travel for leisure, business, and education purposes. When traveling, they meet people from different cultures and are exposed to a new and exciting world. It has increased the tourism market, producing millions of jobs globally, and benefiting people economically and socially. Tourism is one of the primary generators of economic prospects for residents (especially women) in host destinations, particularly in developing countries. Not only in urban areas but even in rural areas, where not many prospects of employment were available, tourism has provided the opportunity to earn. Around $60-70 \%$ of the tourism workforce involves women (International-Labour-Office, 2001). However, the division of labor in the tourism industry is profoundly gendered (Kinnaird \& Hall, 1996). The opportunities provided to both men and women are unequally distributed (Swain, 1993). Women are mostly involved in temporary, less skilled, and seasonal jobs like cleaning or cooking and are paid less than men who are recruited for more senior positions such as managers and owners. The jobs associated with women are not classified as skilled even though it requires skills, and if they are doing unskilled work, it further devalues them. It is due to the cultural norms that are prevalent against women in society. However, tourism has provided opportunities for women to stand on their feet and earn an independent income. It has empowered them economically and has improved their living conditions to some extent. However, with sociopolitical barriers present in society, there has been limited female participation in tourism.

The tourism industry is considered to have the potential to achieve the goals of empowerment. UNWTO is working towards enhancing the quality of women's lives positively through tourism development, promoting sustainability, and inclusive development. It dedicated the theme of World Tourism Day 2007: "tourism opens doors for women," raising gender issues and endorsing women empowerment and gender equality. In the UNWTO report (2010), Secretary-General Taleb Rifai quoted that "Tourism plays a crucial role in empowering women politically, socially and economically and more must be done to achieve gender equality."

According to the UN Convention on Human Rights, all women should have equal rights relative to men. However, tourism development programs \& initiatives planned and implemented are generally gender-blind and adapt to existing patterns of gender relations, not tackling the issues of gender disparity (Longwe, 2002). Since women lack access to education, exposure, and societal support, they face more challenges. The government actions should contribute to the overall development of women so that rather seen as beneficiaries of some welfare program, they participate actively in nation-building. Development should not be just confined to economic factors but should also consider social and human aspects (Varghese, 2011). The framework suggested by Scheyvens (2000) highlights that manifold and complex process of empowerment has economic, social, political, and psychological dimensions. In tourism context, economic empowerment occurs when having employment or business opportunities, social empowerment is when tourism increases community cohesion among members, psychological empowerment is when individual's confidence and selfesteem is enhanced and when they recognize and value their communities culture and political empowerment takes place when community members are fairly represented in the political structure, and their voices and concerns are heard (Scheyvens, 2000). These dimensions often overlap and interrelate with each other (Butler, 2017). Economic empowerment may or may not give women equal status in society or free them from gender bias, therefore, it is important to understand the needs and social relationships of women in the community.

Women Empowerment and gender equality are important issues debated in all international institutions. It was stated in World Summit 2005 and agreed by various governments that "progress for women is progress for all." An empowered woman improves their quality of life and contributes to their family and communities' development (Moswete \& Lacey, 2015). Women focus on preserving the local culture and heritage (Cikic, Jovanovic, \& Nedeljkovic, 2018) and also contribute to environmental protection (Mohanty, Chandran, \& Nilmadhab, 2018). As found in a study by Cikic, Jovanovic, \& Nedeljkovic (2018), one of the purposes of women's involvement in rural tourism in Vojvodina was to preserve and promote their culture, customs, traditions, and rural way of life. Women are also considered to be close to nature who better understands the needs of the environment (Mohanty et al., 2018). There are also many successful environmental movements led by women globally, like the Chipko Movement in India, the Green Belt Movement in Kenya, and many more (Mapo \& Gunwal, 2019). These cultural and environmental resources are vital tourism products, and women can help preserve and maintain these resources. Tourism also provides 
business opportunities for women with little investment and better working conditions. These businesswomen, in turn, recruit other women providing further employment opportunities (Movono \& Dahles, 2017). Involving women in every aspect of tourism development can be beneficial for both women and the tourism industry. Therefore, empowering women not just economically but also socially and politically can lead to sustainability. We will be discussing the social and political aspects of women empowerment in the next section.

\section{Social empowerment}

In general, Social Empowerment is obtained when communities become cohesive and work together towards shared goals (Cole, 2006). In the tourism context, it is felt when community members work together to build successful tourism ventures and revenue generated is used for community development (Scheyvens, 2000). A study by McMillan, O'Gorman, \& MacLaren (2011) showed that women's group working in tourism industry contribute a part of their earning from tourism activities in the development of the community by building trails and cleaning the villages. It shows a real spirit of community among women members. Social Empowerment also means women having equal status in society. It enables women to socialize, participate in decision-making, control their lives in terms of reproduction, marriage, freedom from domestic slavery, and have opportunities for education and skill enhancement (Hovorka, 2014; Jutting \& Morrisson, 2005; Scheyvens, 2000). On the contrary, women's social disempowerment occurs due to illiteracy, social exclusion, lack of prospects, lack of participation in decision making, financial dependence, and patriarchal system (Moswete \& Lacey, 2015).

Social power structures present in societies play a crucial role in creating and sustaining inequalities between men and women and are hard to change (Varghese, 2011). Women acquire a subordinate position in society, still requiring their husband's permission to work because of the social norms, limiting the fiscal activities in which women may partake. The male-dominated societies have accepted female participation in the tourism industry as women are mostly concentrated in informal jobs, which are mostly the extension of their domestic household work like housekeeping, cooking, etc. (Elmas, 2007). It can be seen in MB Swain's (1993) study that women of the Kuna community of Panama were involved in ethnic mola artwork but depended on men for its marketing because they were not allowed to work outside their community. In her study, Tucker also argued that women were not allowed to interact with tourists, which strictly remains men's job (Tucker \& Boonabaana, 2012). Therefore, besides providing economic independence, it is essential to analyze the norms and customs of a patriarchal society and act accordingly to ensure a suitable working environment for women free from all inequalities enabling them to realize their full potential achieving social empowerment. However, these norms are deeply embedded in any society and take time to change.

\section{Political empowerment}

Political empowerment refers to the ability of varied interest groups, including youth and women, within a community to be represented and their voices heard in public affairs. Political empowerment of women enables them to have access to power and authority, access to voting, control over decision making, and political representation (Scheyvens, 2000; Stanistreet et al., 2007). Inequalities in political representation give powerful groups opportunities to form decisions in their favor (UNDP, 2019).

Longwe (2002), in her study, stated that the political empowerment of women could be classified into two ways: (i). women representation in public affairs outside the household. (ii). Women's involvement in non-economic decision making inside the household. In societies around the world, men are the "head of the household" (Longwe, 2002). Despite gaining financial power, women still do not have the authority to make decisions at the household level. Even outside the household, men have the power of decision making (Longwe, 2002). Gender disparity can be seen on the political front. How women are represented in the political structure outside their household is a debated issue. Though in many countries, they have equal voting rights, they are underrepresented at the political level. According to the UN (2015), only one out of five women are members of the lower or single houses of parliament. They face various obstacles to participate in political affairs. Despite proving their potential as good leaders and being agents of change, they are often marginalized due to discriminatory laws and gender gaps. From the village panchayats to national parliaments to international organizations worldwide, women representation is still minimal. Even though changes can be seen in most countries at local, national, and global levels, yet the progress is slow (UN, 2015). In the tourism context, political empowerment occurs when women are equally and 
fairly represented at a political level and have a platform to share their ideas and concerns related to the tourism development process (Scheyvens, 2000). They should be involved at all levels of development and execution of the tourism projects and take the authority to make appropriate decisions. A study showed that women in the political arena have different priorities than men. They raise their voices against government development programs and emphasize on women's problems and work toward building women's networks (Kabeer, 2005).

\section{Social and political barriers women face in tourism industry}

In many societies, women have fewer rights than men in terms of education, employment, land inheritance, healthcare, and access to other resources. Their experiences are also different in different societies, and they have to face many barriers while trying to bring social change (Wallace \& March, 1991) that constrains them to achieve social mobility and active participation in the tourism industry. To achieve overall women empowerment, these issues need to be addressed.

\section{Gender stereotyping}

Mostly in developing countries, gender inequalities are prevalent in all aspects of society, which creates gender gaps at all levels (Hosni \& Lundberg, 2005), where women are responsible for the domestic chores while men would take care of finances. Therefore, if they get involved in outside work like in tourism activities, they are often subjected to the scrutiny of their character by society. Besides, women often do not get the chance or miss out on the opportunities to take part in formal employment and are mostly involved in informal jobs that are predominantly feminine (Scheyvens, 2000). In the tourism industry, the jobs associated with women and done by women are considered unskilled, and the same job done by men are taken seriously and considered skilled for them (Elmas, 2007). For example, many men in the hospitality sector are taking cooking as a job, which is regarded as women's work. Women are not even allowed to take any non-traditional jobs, such as tour guides and drivers, as it is regarded as a men's activity and not suitable for them by the communities (Wilkinson \& Pratiwi, 1995).

\section{Patriarchal system}

Since men have the power and authority in the household, and even outside, women are not allowed to do anything against men's wishes (Longwe, 2002). Women are not involved in household decision making, and even if they do involve, major decisions are still taken by men. They require men's permission to work outside or start their own business, and men only decide what jobs women should engage in. Women are also not allowed to interact with other men outside the community, as it is seen negatively. Therefore, in many communities, women associated with the tourism business are limited to jobs in which they do not have to interact with tourists (Panta \& Thapa, 2018). They are not allowed to do male jobs as they are considered physically weak and are culturally bound (Elmas, 2007).

\section{Dual responsibility}

Women have dual roles. One role is of a working woman in which she is paid, and the other one is of a homemaker in which she is not paid anything (Sahay, 1998). Women working in the tourism industry face difficulty in keeping the balance in social reproduction and work responsibility as they are expected to fulfill the responsibility of taking care of their family, despite working outside. Women involved in family tourism businesses and helping their husbands are considered their duty, which often remains unpaid and unrecognized. Handling dual responsibility makes women work longer hours than men, which sometimes leads to stress and worsens their health (Panta \& Thapa, 2018). They do not have free time for themselves and often sacrifice their sleep to fulfill their responsibilities. It also reduced their social interactions with their neighbors and relatives. Due to low wages, they are often unable to hire someone for their help (Gentry, 2007). However, their contributions often go unnoticed, and they do not get equal status in society.

\section{Lack of education and skills}

Access to education is one of the critical factors to empower women (UNFPA, 1994). The responsibility for childcare and other domestic work limited women's access to education and other skill development opportunities. According to World Women Report (2015), globally, two-thirds of illiterate women are mostly in developing countries. The disparity can be seen in societies where boys have more access to education than girls. Girls who do not go to school either help in housekeeping or get married at an early age. They do not have many options (Gentry, 2007). Though tourism provides an option to earn an income for girls and women, the majority are employed in the 
tourism industry into low-paid and low-skilled jobs due to their lower education level and lack of expertise (Kabeer, 2005). Uneducated or less-educated women face many challenges in the tourism industry as they have to interact with foreign tourists, which demands language proficiency and communication skills (Panta \& Thapa, 2018). Meaningful access to education and skills enable women's awareness of their status and rights. It boosts their self-confidence and enables them to participate fully in the development process (UNFPA, 1994) and be in the competition within the tourism industry (Radovič-Markovič \& Živanovič, 2019).

\section{Lack of Access to Information}

Access to information is a prerequisite for tourism development and empowerment. The information regarding tourism benefits and disadvantages should be equally distributed among the individuals as it is a fundamental right. Yet, gender gaps can be seen in the distribution of information. Statistics show that women's access to information is low relative to men (Narayan, 2002; Longwe, 2002). As shown in a study on gender inequalities in rural tourism in Vojvodina, women's lack of knowledge and information was higher than men. However, they both showed interest in acquiring it (Cikic, Jovanovic, \& Nedeljkovic, 2018). Having adequate, timely, and relevant information empowers women to make effective decisions that benefit the community, benefit from the opportunities that come their way, know their rights, exercise them properly, and actively participate in public affairs (Narayan, 2002).

\section{Lack of participation in political affairs}

In a male-dominated society, women are often excluded from community engagement. Even if they involve in public affairs, they are underrepresented, and their voices usually go unheard (Foley, Grabowski, Small, \& Wearing, 2018). They are not included in decision makings related to tourism as equally as men. The organizational structures formed from the international level to the community level tend to reflect the patriarchal system (Longwe, 2002). Women's presence in such organizations is only a 'token' one (Kabeer, 2005). They may enjoy the privileges but do not have any power or control over any decision making.

\section{Socio-political change through tourism development - analysis of case studies}

The previous section of this work highlighted various socio-political barriers related to women empowerment. This part tries to explore the various changes brought into such issues through tourism development. The case study approach has been adopted to see how women, through involvement in tourism activities, tried to negotiate with men to minimize such issues and achieve empowerment.

\section{Uganda) \\ Case Study I (Women negotiating to overcome the gender barriers in Mukono Parish, \\ Mukono Parish, a small town in Uganda, had minimal economic opportunities, and people} depended mostly on subsistence farming. The majority of men migrated to nearby towns and cities for better jobs, and few left behind got indulged in alcohol and womanizing habits. The emergence of tourism provided the town with a profitable livelihood option. For the first time, women also got the opportunity to earn an income of their own. They got involved in a wide range of activities, including cultural performances, handicraft business, hospitality, gardening, and tour guides. However, they were involved in low-paying, insecure jobs relative to men.

In many households, women were the sole supporters, and tourism provided these women with the opportunities to earn, provide for their families, and bring change in their lives. With their own income, women were now able to invest in property, of which they are the sole owner. With changes taking place through tourism development, they improved their status in society, formed social networks, and increased self-confidence and self-belief. Though women had to face many barriers and challenges to work in the tourism industry, they negotiated and renegotiated with men to overcome them. Subsequently, men started to appreciate women's development efforts and changed their negative attitudes towards them (Tucker \& Boonabaana, 2012).

\section{Case Study II (Empowerment of Indigenous women of the Shiripuno, Ecuador through Ecotourism)}

After being exploited long by oil companies, the Shiripuno community wanted a sustainable livelihood option. Ecotourism projects in their province became that alternative, which benefitted them economically, socially, and environmentally. Indigenous women of Shiripuno created a 
legitimized association Amukishmi and started an ecotourism venture. The women associated with Amukishmi run an ecolodge that benefited them financially and increased their social status. The changes could be seen at the social level where men helped women in household chores and a business venture by sharing the responsibility in reducing their workload. Domestic violence was also reduced. It enabled women to participate in development efforts actively. The association helped women to be more aware of their rights and have a voice and vote in the development of their community. Women not only gained personal income, but they also contributed money for community development. Shiripuno being a patriarchal society, making it difficult for women, in the beginning, to get permission from their husbands to work in the venture. However, women's involvement in the Ecotourism project contributed to strong bonding among women and improved relations between men and women (Marcinek \& Hunt, 2015).

\section{Case Study III (Empowering Women through Cultural Tourism in Botswana)}

Though the Botswana Government has made a few changes in traditional laws for women's advancement, rural areas remain male-dominated. Women suffer discrimination and do not get the opportunities to realize their potential and remain disempowered. The government created a tourism policy supporting community-based cultural tourism and encouraged women to participate by providing jobs and entrepreneurship opportunities. Various schemes started for women, which enabled them to engage in a wide range of activities, including pottery, art \& craft business, and cooking. They also engaged in unconventional jobs such as tour guides and site officers. The study showed that women, whether employed or self-employed, felt the sense of freedom. They freed themselves from dependency on men, depravity, and feeling of desolation as they found some purpose in their lives by being productive and doing good for their community. They became economically, socially, and psychologically empowered. They were able to make their own decisions, purchase lands, contribute to family income, provide better education for their children, travel, pursue additional business interests, and interact with foreign tourists with confidence. However, Women were not able to get formal education due to tourism activities, but they pursued vocational training to upgrade their skills required to be self-reliant. Besides, they are also educating their kids, especially their girl child, thus empowering future generations. According to women of Botswana, men always supported in their empowerment. The government action plan of introducing cultural tourism in Botswana has opened the door of opportunities for women. However, women still face some hindrances that need to be addressed: lack of access to capital, low education level, low earnings, and lack of involvement in planning and implementing tourism programs. Despite these barriers and a patriarchal system, women were able to pave their way, progressing from passive to active participation (Moswete \& Lacey, 2015).

\section{Vietnam)}

Case Study IV (Community-Based Ecotourism and Women Empowerment in Northern

The community-based ecotourism project benefited women by providing them with various income opportunities - women involved in traditional and non-traditional jobs. In the beginning, to work as guides, women had to convince their husbands, as it was thought to be an inappropriate job for them. However, with time, men showed their support for them. They even shared their responsibilities by helping women in domestic chores. The community-based ecotourism project enabled both men and women to understand change in gender roles and relations. Now women have control over their income and are involved in economic and non-economic decision making at the household level. However, at the community level, men are still favored to make any decisions. Although women involved in ecotourism project have equal participation in decision-making and even take new leadership roles. It can be seen, in a sense, when a woman was appointed as head of the CBET cooperative. The project also helped women gain access to education and skill development through training programs and workshops. These benefits increased women's participation in the project and boosted their confidence. Though few women still face domestic violence, since they are aware of their rights, they can raise their voices against these problems (Tran \& Walter, 2014).

\section{Case Study V (Women Empowerment through tourism Entrepreneurship in Fijian Village)}

With the opening of a resort back in the 70s in Vatuolalai (Fijian village), women got full-time employment opportunities, which provided them with stable income. It later encouraged them to start their businesses. With the Women Development Association's (WDC) help, few women got the sanction to sell handicrafts to visitors. It shows social empowerment where women are working together in tourism development. WDC helped women by providing them a forum where they could collectively discuss their concerns, issues, and new ideas to participate in tourism businesses. Women started doing various kinds of business, such as handicraft, parlor services, accommodation, restaurant, and money lending. With success in their projects, they were able to gain recognition and 
power in the community. Women who were already doing business recruited other women taught them, and encouraged them to start their own business. They showed others the way to involve in the tourism industry and initiated the empowerment process. Women were equally represented in village meetings, and their voices were heard. They even occupied important positions at the village political level. Women with their entrepreneurial spirit have enabled them to gain confidence, greater autonomy over their decisions, and better working conditions. They also enhanced their skills by doing workshops organized by the government and also on their own, which helped them diversify their business. These changes did not occur overnight as women had to face many rigid cultural barriers that were difficult to change. They identified the causes of oppression and inequality, showed their ability, and fought for their rights (Movono \& Dahles, 2017).

\section{Discussion}

Social norms and traditions have stayed in the communities for too long and deeply embedded in the countries' history and culture (UNDP, 2019). These norms and traditions are different in different places and therefore changes, and their outcomes are also place-specific (Tucker \& Boonabaana, 2012). As can be seen in the case studies, changes brought in women's lives are different in different communities. However, change is a universal phenomenon and is inevitable. Therefore, we can see how barriers are reducing, and new gender relations and power structures are taking place through tourism. However, there may be other factors that have helped to bring these changes, but tourism played a crucial part in providing opportunities for women all around the world who otherwise would still be confined in their houses doing household works. Women have used tourism as a vehicle for attaining empowerment and development. It provided economic empowerment and helped in poverty reduction (UNWTO, 2010).

Tourism has also benefitted women in rural areas of developing countries by emancipating them from the "economic-sexual" cycle (Gentry, 2007). It helped them to get freedom from being dependent on others for existence. They are now able to challenge and oppose the cultural norms and unfair treatments that take place against them. Women are coming out of their comfort zones and taking up new roles, not confining themselves to feminine work. With job opportunities in tourism, they can solely support their families (Tucker \& Boonabaana, 2012; Tran \& Walter, 2014). Men are also changing their attitudes and helping women by sharing responsibilities. It has reduced the barriers of gender stereotyping and work burden on women (Marcinek \& Hunt, 2015; Tran \& Walter, 2014). Tourism also helps hosts by providing the chance to interact with tourists and learn from each other's cultures as both of them have different sets of perceptions, motivations, and cultural values. This cross-cultural interaction helps women of the host destination know about the outside world. This interaction may lead to a change in social norms (Moswete \& Lacey, 2015). They gain new knowledge, become aware of their rights and unjust practices prevalent in society, and stand together to fight against it, demanding equal status in the workplace, home, and society. Governments of many countries, NGOs, and Self-Help Groups also play a critical role in empowering women and strengthening them for their active participation in the nation's development. They are helping women by enhancing their skills and capabilities by training them and providing them with a platform to discuss their issues and be self-sufficient (Movono \& Dahles, 2017; Tran \& Walter, 2014; (Marcinek \& Hunt, 2015). Tourism has made them realize their potential and abilities, which they were unaware of and are now actively involving in decision making at the domestic and the communal level.

However, these changes did not happen in one day or one year. Old norms and traditions don't die that easy. It takes a long time to change. Women still face many barriers and go through difficulties to attain equal status in the community. In many societies, they still have to do things according to society's cultural norms; otherwise, they had to face the consequences. However, change is visible but will take time to mitigate the barriers to women empowerment fully. It is important to involve women at all levels of the tourism development process and encourage them to share their ideas and concerns related to it as they are also an important part of society. Their needs should be understood and taken into consideration when establishing a tourism project in a community. Capacity building programs and awareness programs should be introduced to focus on women's issues and roles in their workplaces and communities. The channelized flow of information between the government and the citizens and equal distribution of information among citizens is vital for improving government programs' outcomes. 


\section{Conclusion}

This study analysed the issues faced by women at the social and political levels and changes tourism brought on women empowerment. It has been observed that every society has different cultures and traditions, and therefore the experiences of women are also different at different destinations. In some communities, women have been actively participating in tourism activities supported by their families and societies, and at other destinations, even though they get permission to work outside, they are less supported. However, the issues never stopped women from working, and they seized the opportunities that came their way. Tourism acted as a facilitator and directed them towards empowerment. Tourism helped them in challenging entrenched perspectives about gender roles and enabled women to break the cycle where they are just thought to be homemakers. Tourism has helped them increase their status in society and improved the standard of living. It also provided them a sense of self-confidence, self-respect, and a feeling of happiness and autonomy, all of which led to women empowerment.

Empowered women, empower their families, and also their communities. Economic independence may be the first step towards empowerment, but it may not be enough. Women need to be empowered from within. It can be achieved when, on the one hand, they have the support of their family and the community. On the other hand, they have the freedom to decide for themselves and are recognized equally for their contribution. Hence it is also essential to study non-economic factors for the overall empowerment of women and, subsequently, the nation's development.

\section{Funding}

The author(s) received no financial support for the research, authorship, and/or publication of this article.

\section{Declaration of conflicting interests}

The author(s) declared no potential conflicts of interest with respect to the research, authorship, and/or publication of this article.

\section{Citation information}

Singhania, O., Swain, S., \& George, B. (2021). Women empowerment in a traditional masculine industry: Tourism in context. Economics, Management and Sustainability, 6(2), 60-71. doi:10.14254/jems.2021.6-2.5.

\section{Reference}

Butler, G. (2017). Fostering community empowerment and capacity building through tourism : perspectives from Dullstroom , South Africa. Journal of Tourism and Cultural Change, 15(3), 199-212. https://doi.org/10.1080/14766825.2015.1133631

Cikic, J., Jovanovic, T., \& Nedeljkovic, M. (2018). Business and/or pleasure - Gender (In)equalities in rural tourism in Vojvodina. Journal of Agricultural Science and Technology, 20(7), 1341-1352.

Cole, S. (2006). Information and empowerment: The keys to achieving sustainable tourism. Journal of Sustainable Tourism, 14(6), 629-644. https://doi.org/10.2167/jost607.0

Elmas, S. (2007). Gender and tourism development: A case study of the Cappadoccia Region of Turkey. 302-314.

FAO. (2010). Basic Concepts of Gender.

Ferguson, L. (2011). Promoting gender equality and empowering women? tourism and the third millennium development goal. Current Issues in Tourism, 14(3), 235-249. https://doi.org/10.1080/13683500.2011.555522

Foley, C., Grabowski, S., Small, J., \& Wearing, S. (2018). Women of the Kokoda: From poverty to empowerment in sustainable tourism development. Tourism, Culture and Communication, 18(1), 21-34. https://doi.org/10.3727/109830418X15180180585158

Gentry, K. M. (2007). Belizean women and tourism work: Opportunity or impediment?. Annals of Tourism Research, 34(2), 477-496. https://doi.org/10.1016/j.annals.2006.11.003 
Hamzic, E., \& Ekbladh, M. (2017). Women in Tourism: Exploring the Links between Women's Skills Development, Empowerment and Employment TT-Kvinnor inom turismen: Ett utforskande kring kvinnors kompetensutveckling, egenmakt och arbete (swe): Vol. Independent thesis Basic level (degree of Bachelor).

Hosni, D., \& Lundberg, C. (2005). The status of women revisited : The case of Nepal.

International-Labour-Office. (2001). Human resources development, employment and globalization in the hotel, catering and tourism sector. Sectoral Activities Programme, 2001.

Kabeer, N. (2005). Gender equality and women's empowerment: A critical analysis of the third Millennium Development Goal. Gender and Development, 13(1), 13-24. https://doi.org/10.1080/13552070512331332273

Kinnaird, V., \& Hall, D. (1996). Understanding tourism processes: A gender-aware framework. Tourism Management, 17(2), 95-102. https://doi.org/10.1016/02615177(95)00112-3

Longwe, S. H. (2002). Addressing Rural Gender Issues : A Framework for Leadership and Mobilisation. (October).

Marcinek, A. A., \& Hunt, C. A. (2015). Social capital, ecotourism, and empowerment in Shiripuno, Ecuador. International Journal of Tourism Anthropology, 4(4), 327. https://doi.org/10.1504/ijta.2015.074005

McMillan, C. L., O'Gorman, K. D., \& MacLaren, A. C. (2011). Commercial hospitality: A vehicle for the sustainable empowerment of Nepali women. International Journal of Contemporary Hospitality Management, 23(2), 189-208. https://doi.org/10.1108/09596111111119329

Mohanty, P., \& Chandran, A. (2018). Poverty Alleviation and Women Empowerment through Tourism Development - an Explorative Study of Model Ventures. Atna - Journal of Tourism Studies, 13(1), 59-74. https://doi.org/10.12727/ajts.19.5

Mohanty, P., Chandran, A., \& Nilmadhab, S. (2018). Promoting Gender Sensitivity and Environment Protection through Sustainable Tourism Development: A Review. Journal of Tourism.

Moswete, N., \& Lacey, G. (2015). "Women cannot lead": empowering women through cultural tourism in Botswana. Journal of Sustainable Tourism, 23(4), 600-617. https://doi.org/10.1080/09669582.2014.986488

Movono, A., \& Dahles, H. (2017). Female empowerment and tourism : a focus on businesses in a Fijian village Female empowerment and tourism : a focus on businesses in a. Asia Pacific Journal of Tourism Research, O(0), 1-12. https://doi.org/10.1080/10941665.2017.1308397

Narayan, D. (2002). Empowerment and poverty reduction: A sourcebook. The World Bank.

Panta, S. K., \& Thapa, B. (2018). Entrepreneurship and women's empowerment in gateway communities of Bardia National Park, Nepal. Journal of Ecotourism,17(1), 20-42. https://doi.org/10.1080/14724049.2017.1299743

Pritchard, A. (2014). Gender and Feminist Perspectives in Tourism Research. The Wiley Blackwell Companion to Tourism, 314-324. https://doi.org/10.1002/9781118474648.ch25

Radovič-Markovič, M., \& Živanovič, B. (2019). Fostering green entrepreneurship and women's empowerment through education and banks' investments in tourism: Evidence from Serbia. Sustainability (Switzerland), 11(23). https://doi.org/10.3390/su11236826

Sahay, S. (1998). Women and Empowerment: Approaches and Strategies (1st ed.). New Delhi: Discovery Publishing House.

Scheyvens, R. (2000). Promoting women's empowerment through involvement in ecotourism: Experiences from the third world. Journal of Sustainable Tourism,8(3), 232-249. https://doi.org/10.1080/09669580008667360

Spenceley, A., \& Meyer, D. (2012). Tourism and poverty reduction : theory and practice in less economically developed countries. 9582. https://doi.org/10.1080/09669582.2012.668909

Swain, B. (1993). Women Producers. 20, 32-51.

Tran, L., \& Walter, P. (2014). Ecotourism, gender and development in northern Vietnam. Annals of Tourism Research, 44(1), 116-130. https://doi.org/10.1016/j.annals.2013.09.005 
Tucker, H., \& Boonabaana, B. (2012). A critical analysis of tourism, gender and poverty reduction. Journal of Sustainable Tourism, 20(3), 437-455. https://doi.org/10.1080/09669582.2011.622769

UNDP. (2019). Human Development Report 2019 Beyond income, beyond averages, beyond today: Inequalities in human development in the 21st century.

UNWTO. (2010). Second edition Global Report on Women in Tourism.

Varghese, T. (2011). Women empowerment in Oman: A study based on Women Empowerment Index. Far East Journal of Psychology and Business, 02(02), 37-53.

Wallace, T., \& March, C. (1991). Barriers to women's development. Changing Perceptions: Writings on Gender and Development.

Wilkinson, P. F., \& Pratiwi, W. (1995). Gender and tourism in an Indonesian village. Annals of Tourism Research, 22(2), 283-299. https://doi.org/10.1016/0160-7383(94)00077-8

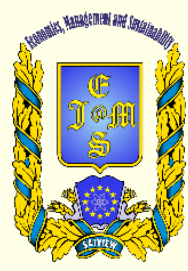

(c) 2016-2021, Economics, Management and Sustainability. All rights reserved.

This open access article is distributed under a Creative Commons Attribution (CC-BY) 4.0 license.

You are free to:

Share - copy and redistribute the material in any medium or format Adapt - remix, transform, and build upon the material for any

purpose, even commercially.

The licensor cannot revoke these freedoms as long as you follow the license terms.

Under the following terms:

Attribution - You must give appropriate credit, provide a link to the license, and indicate if changes were made.

You may do so in any reasonable manner, but not in any way that suggests the licensor endorses you or your use.

No additional restrictions

You may not apply legal terms or technological measures that legally restrict others from doing anything the license permits.

Economics, Management and Sustainability (ISSN: 2520-6303) is published by Scientific Publishing House "CSR",

Poland, EU and Scientific Publishing House "SciView", Poland

Publishing with JEMS ensures:

- Immediate, universal access to your article on publication

- High visibility and discoverability via the JEMS website

- Rapid publication

- Guaranteed legacy preservation of your article

- Discounts and waivers for authors in developing regions

Submit your manuscript to a JEMS at http://jems.sciview.net or submit.jems@sciview.net

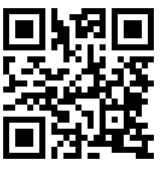

